\title{
Addition to the Flora of Canada? A Specimen from the Arctic Archipelago, Northwest Territories Links Two Allopatric Species of Alkali Grass, Puccinellia
}

\author{
L. L. Consaul, L. J. Gillespie, and K. I. MacInnes ${ }^{1}$ \\ Canadian Museum of Nature, P.O. Box 3443, Station D, Ottawa, Ontario K1P 6P4 Canada; email: lconsaul@mus-nature.ca; \\ lgillespie@mus-nature.ca. \\ ${ }^{1}$ Box 21, Site B, 1052 Cedarwood Drive, Verona, Ontario K0H 2W0 Canada; email: macinnes@kingston.net
}

Consaul, L. L., L. J. Gillespie, and K. I. MacInnes. 2005. Addition to the flora of Canada? A specimen from the Arctic Archipelago, Northwest Territories links two allopatric species of alkali grass, Puccinellia. Canadian Field-Naturalist 119(4): 497-506.

A single herbarium specimen from Banks Island in the Canadian National Herbarium, Ottawa, is closest to Puccinellia wrightii (Puccinellia sect. Pseudocolpodium). This would represent a species new to Canada and an extension of over $1100 \mathrm{~km}$ from the previously known range in NW Alaska and NE Russia. The morphological characteristics of this specimen are compared with all taxa in P. section Pseudocolpodium and the North American P. arctica aggregate. Principal components analysis supports placement of this specimen in $P$. section Pseudocolpodium near $P$. wrightii, where it contributes to a morphological continuum between this species and P. vahliana. The new combination Puccinellia wrightii var. flava is made and a map of the current known distribution of the species in $P$. section Pseudocolpodium is presented.

Key Words: Alkali grass, Puccinellia wrightii, Puccinellia section Pseudocolpodium, principal components analysis, Canadian Arctic Archipelago.

Alkali grasses (Puccinellia Parl.) are tufted, pioneering grasses which are usually found along the seashore or on interior salt pans and alkaline marine sediments in both temperate and arctic regions. They have soft, often inrolled leaves, panicles with several florets per spikelet, small glumes that are shorter than the awnless lemmas, and lemmas with rounded backs. Puccinellia is currently the largest Arctic grass genus.

Puccinellia has a long history of taxonomic uncertainty and plants are often difficult to identify. Fernald and Weatherby (1916, page 1) called it "even to agrostologists, one of the most perplexing groups of grasses...," Polunin (1940, page 67) commented that: "the characters are variable... $[P$. angustata $]$ is a most unsavoury aggregate...," and Davis (1993, page 202) called it "one of the more controversial genera in the grass family in terms of species delimitation." Whereas over 300 species have been described worldwide, 30 to 80 species have been accepted over the span of the last 20 years (Gould and Shaw 1983; Davis 1983; Watson and Dallwitz 1999*).

During examination of specimens for morphological studies on alkali grasses of the Canadian Arctic Archipelago (CAA) (Consaul and Gillespie 2001) and the grasses of the CAA (Aiken et al. 2000*), a herbarium specimen was found that did not key to any known Canadian grass species and was not discussed in either of these works. It had been collected by Kaye MacInnes during an ecological survey with John Lambert (Carleton University) of an area on Banks Island near Egg River. This area was under study because it was proposed as an International Biological Program (IBP) site. Although not designated as an IBP, the area falls within the Banks Island No 1 Migratory Bird Sanctuary, which protects the nesting habitat of the Lesser Snow Goose, Chen caerulescens caerulescens. Knowledge of baseline botanical information in this area, especially from specimens in the 1970s, is of interest because Snow Goose colonies have increased dramatically in recent years (McRae et al. 1994). At the Banks Island sanctuary the geese are now foraging further inland and upland than their original grounds in the valley of the Big River (Jim Hines, Natural Resources Canada, personal communication, 2003). While geese feed commonly on P. phryganodes, a stoloniferous species that grows in low saline environments in the area, the Puccinellia specimen in question was growing on upland slopes where the geese have been spreading.

Puccinellia in the North American Arctic may be placed into three sections of the classification by Tzvelev (1976). Puccinellia section Paralochloa contains the stoloniferous species $P$. phryganodes (Trin.) Scribn. \& Merr. Puccinellia section Puccinellia, containing most species in the CAA, has glumes that are relatively uneven in size, with the first glume being less than $1 / 2$ the length of the first lemma, and usually short anthers. The $P$. arctica aggregate with long anthers, first recognized by Polunin (1959) and endemic to North America, likely belongs in this section but has not been formally placed here because the sectional classification was established for species in

\footnotetext{
* See Documents Cited section
} 
Russia. Puccinellia section Pseudocolpodium has glumes that are relatively even in size, with the first glume usually over $1 / 2$ the length of the first lemma, fairly long anthers, and thick, crinkled roots. Worldwide, six species have been described in this section: $P$. beringensis Tzvelev, $P$. byrrangensis Tzvelev, $P$. colpodioides Tzvelev, P. jenisseiensis (Roshev.) Tzvelev, $P$. vahliana (Liebm.) Scribn. and Merr., and $P$. wrightii (Scribn. \& Merr.) Tzvelev. The last two species, of which the latter is represented by two varieties (see under Taxonomy below), were originally described in the genus Colpodium. Puccinellia vahliana is the only Canadian species; $P$. wrightii is from Alaska and Russia and is the next closest geographically; and the other species are from Russia.

Previous determinations by S. G. Aiken (Canadian Museum of Nature) had placed the Banks Island specimen in Puccinellia arctica (Hooker) Fernald and Weath. (in 1989), and later in P. agrostidea T. J. Sørensen (in 1994) of the P. arctica aggregate owing to its long anthers and fairly uneven glumes. In early principal components analyses for the morphological study of Puccinellia by Consaul and Gillespie (2001), this specimen did not associate with any groups. Upon reexamination of the specimen, LLC identified it (in 2000) as "P. vahliana $\times$ ?" of section Pseudocolpodium because it had relatively long glumes and thick, crinkled roots.

This paper presents the findings of our investigation into the identity of this specimen. The specific objectives are (1) to confirm whether this taxon belongs to the large-anthered $P$. arctica aggregate, or to $P$. section Pseudocolpodium, and (2) to determine whether it aligns with a currently described species in the genus.

\section{Methods}

A single specimen from the National Herbarium of Canada (N.W.T., Banks Island, Egg River, Area \#16, K. L. MacInnes s.n., 24 July 1971, CAN 535850) is the subject of this study [collection acronyms follow Holmgren et al. 1990]. We consulted floras of Canada, Alaska, and Russia to determine the putative identification of the specimen. After preliminary screening the specimen was considered to be most closely related to species in Puccinellia section Pseudocolpodium or to members of the North American $P$. arctica aggregate ( $P$. agrostidea, $P$. arctica, and $P$. poacea). We compared the morphological characteristics of the CAN 535580 specimen with specimens of these species.

For $P$. agrostidea (including holotype), P. arctica, $P$. poacea (including holotype), and $P$. vahliana, many specimens were initially examined to determine the range of variation, and a set of ten to 12 specimens of each (Appendix 1) were scored (Table 1). Puccinellia agrostidea was excluded from Table 1 because of the uncertainty of its taxonomic limits, as well as its relatively small florets and anthers. Eight specimens of $P$. wrighti var. wrightii, including the holotype, were obtained and examined. Material was scant or lacking for the other taxa. Only three specimens of $P$. colpodioides were available, and the holotype of P.wrightii var. flava (the only collection known to date) was included. Measurements were made on five separate culms of both the CAN 535850 and the P. wrightii var. flava (Scribn. \& Merr.) Consaul (see Taxonomy section below) collections, and each culm was considered as a separate Operational Taxonomic Unit (OTU), because we had only a single herbarium sheet of each. Data from original descriptions of $P$. beringensis, $P$. byrrangensis, and $P$. jenesseiensis were used for comparison since no specimens were available. Of these, only $P$. byrrangensis was included in the final dataset, since initial examination showed that CAN 535850 keyed out close to this species but not to the other two.

The characters examined were the same as those found useful in separating Puccinellia taxa in the analyses of Consaul and Gillespie (2001: Tables 2 and 4). Two additional qualitative characters, "presence or absence of hyaline margin" and "inflorescence open or contracted," were added since they had been used in keys to these species. For $P$. wrightii and $P$. colpodioides, we kept the data of the non-type herbarium specimens separate from the data of the protologue and the holotype. For P. byrrangensis only data from descriptions was used.

A principal components analysis (PCA) was performed using SYSTAT 7.0 on all taxa for which we had specimens, except one. Puccinellia wrightii var. flava was excluded because its very large spikelet measurements make it clearly different from CAN 535850. A subset of five representative specimens of most taxa, the three of $P$. colpodioides, and the five culms of CAN 535850 were used for the PCA to balance the ordination because of the low number of specimens of some species available for analysis. We recognized that the dispersion of data points in any ordination analyses we performed on these measurements for the single collection of CAN 535850 (likely representing a single plant) might be narrower than the dispersion when each OTU was from a separate population.

The PCA was performed on the quantitative characters listed in Table 1, plus height, ligule length, length of first internode of panicle, palea length, callus hair length, extent of hair from base of lemma, and extent of hair from apex of palea (characters from Consaul and Gillespie 2001). A dataset reduction procedure used by Davis (1983) and established as useful in Consaul and Gillespie (2001) was used here. In this procedure, a group of OTUs which separated from the rest of the data was removed before the remaining reduced dataset was analyzed in a subsequent PCA. In this way, the PCA would calculate the axes on the variation present in the remaining smaller group, thus potentially revealing further groupings among the smaller set of OTUs. 


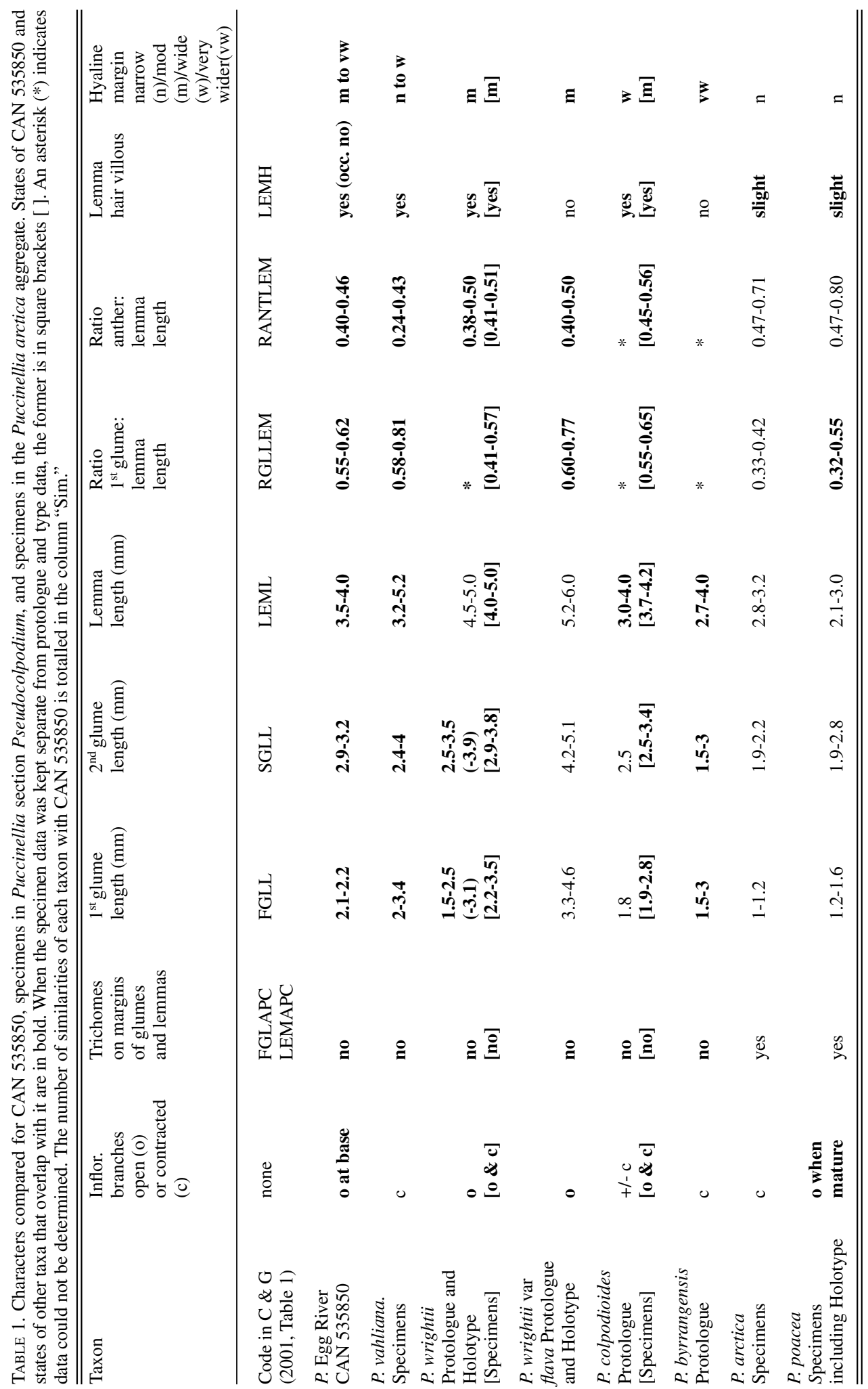




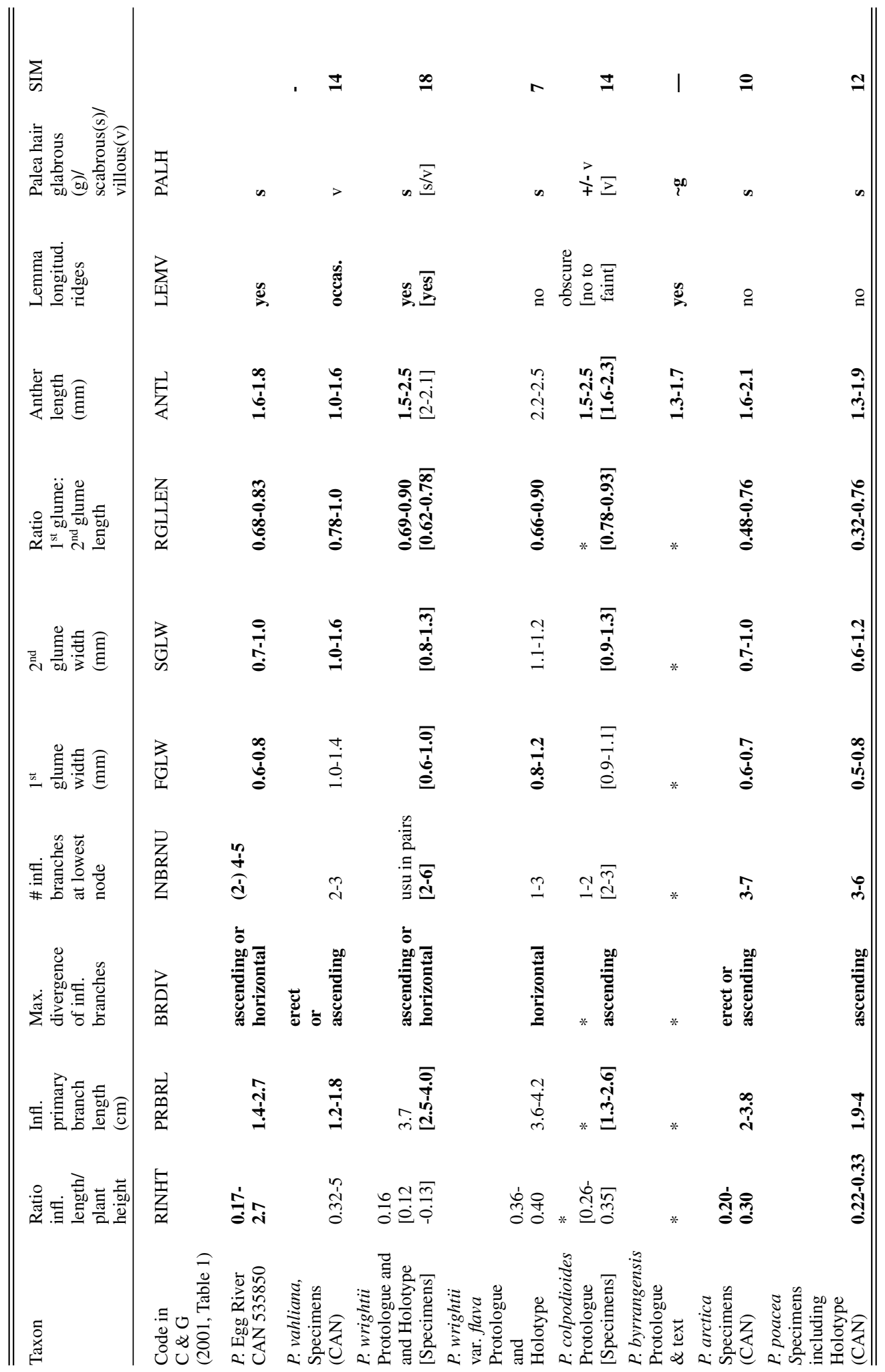




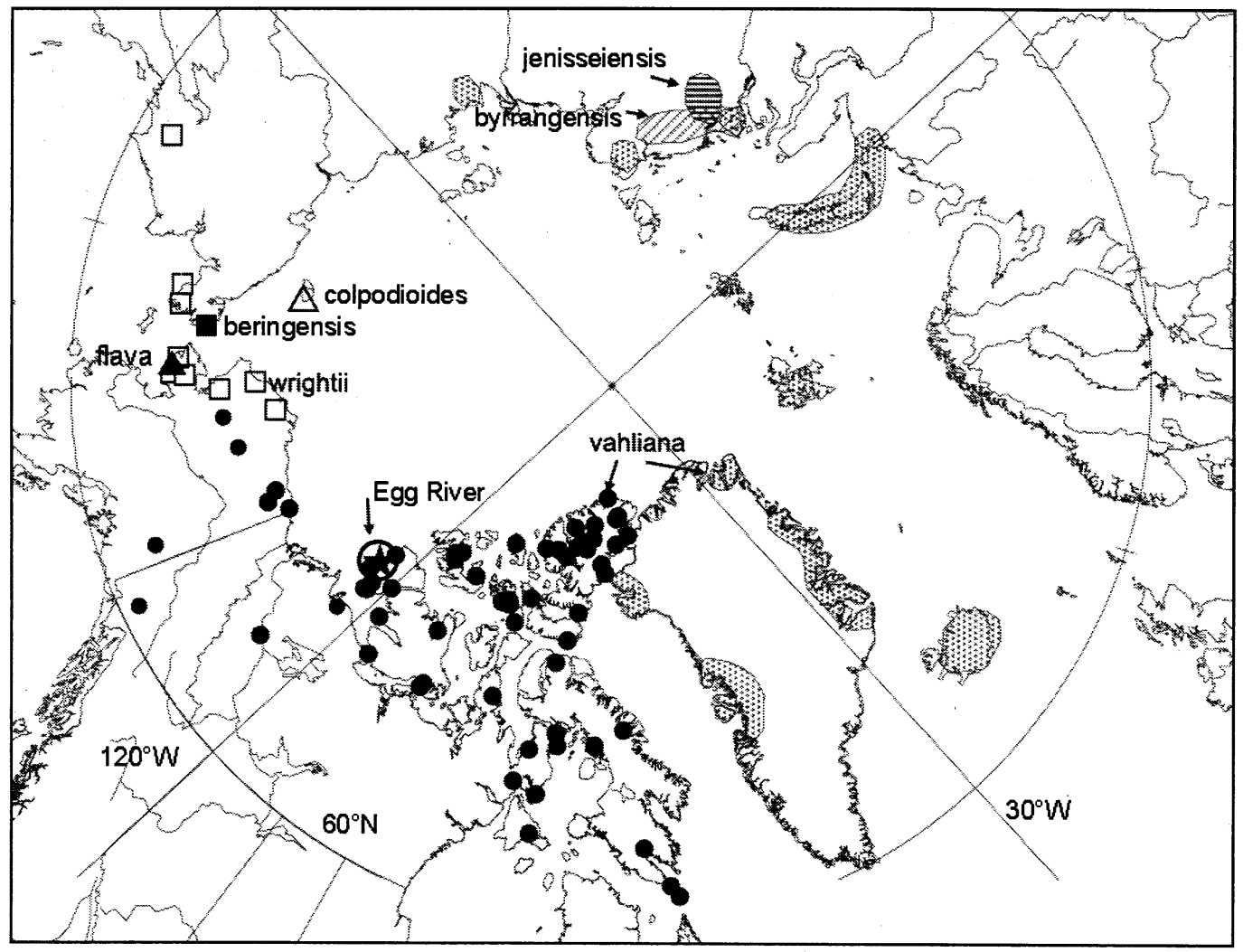

FIgURE 1. Map of species in Puccinellia section Pseudocolpodium. Star in circle = CAN 535850. Solid circles and dot patterns $=P$. vahliana ; open squares $=P$. wrightii; solid square $=P$. beringensis, representing several localities; open triangle $=P$. colpodioides $;$ diagonal hatching $=P$. byrrangensis $;$ horizontal hatching $=P$. jenisseiensis; solid triangle $=P$. wrightii var. flava.

The current distribution of the species in $P$. section Pseudocolpodium was mapped (see Figure 1). The distribution of $P$. vahliana is based on specimens from CAN and DAO (solid circles), as well as the maps in Hultén (1968) (area indicated by dot pattern) and Cody (1996) (Yukon record). The open squares representing $P$. wrightii var. wrightii are based on specimens from CAN, DAO, ALA and US, as well as the dot map in Probatova (1985) and text in Tzvelev (1964). The open triangle of $P$. colpodioides is based on several specimens from CAN and ALA, and text in Tzvelev (1964). The solid triangle representing $P$. wrightii var. flava is from the holotype, the only specimen known. The distribution of $P$. beringensis (closed square) is based on the dot map in Probatova (1985), P. byrrangensis (diagonal hatching) is based on the dot map in Malyshev and Peshkova (1990), and P. jenisseiensis (horizontal hatching) is based on a description of the distribution in Tzvelev (1964).

\section{Results}

A morphological and habitat description of CAN 535850 is given in Appendix 2. Figure 1 shows the distribution of CAN 535850, labelled "Egg River," compared with all the taxa in Puccinellia sect. Pseudocolpodium.

Using Anderson's Flora of Alaska and Adjacent Parts of Canada (Welsh 1974), CAN 535850 keyed out to Puccinellia wrightii (as Colpodium wrightii Scribn. \& Merr.). In Grasses of the Soviet Union (Tzvelev 1976), it keyed out intermediate between $P$. colpodioides (as P. wrightii subsp. colpodioides (Tzvelev) Tzvelev) and P. byrrangensis.

\section{Single characters}

Table 1 presents a morphological comparison of the Puccinellia taxa under study. The values of CAN 535850 and the values that overlap with those of CAN 535850 are highlighted in bold. Figure 2 shows photographs of inflorescences and spikelets comparing CAN 535850 with the other closely related species.

CAN 535850 had 14-18 similarities with taxa in $P$. section Pseudocolpodium (except for $P$. wrightii var. flava) and 10-12 similarities to taxa in the P. arctica aggregate (Table 1, column SIM). The first nine characters in Table 1 show the overlap between CAN 
535850 and species in $P$. section Pseudocolpodium that are different, for the most part, than the values in the $P$. arctica aggregate. One character in Table 1, ratio of inflorescence length to plant height, showed no overlap of CAN 535850 with any members of the $P$. section Pseudocolpodium, but instead showed overlap with members of the $P$. arctica aggregate.

Within $P$. sect. Pseudocolpodium, the taxon with the most similarities to CAN 535850 was $P$. wrightii var. wrightii, overlapping in 18 characters (Table 1). The next closest were $P$. colpodioides (14) and $P$. vahliana (14). The characters that were similar to $P$. wrightii var. wrightii, but not to $P$. colpodioides or $P$. vahliana, are number of branches at lowest node of inflorescence, first glume width, and palea hair.

Inflorescences of CAN 535850 (Figure 2a), $P$. wrightii (Figure 2c), and $P$. poacea (Figure 2e) were typically open, except when young and then closed and contracted. The inflorescence of $P$. vahliana (Figure 2 b) was typically contracted, although sometimes slightly more loosely than in the photograph. The inflorescence of $P$. colpodioides (Figure 2d) was variable in shape, most often being contracted as in $P$. vahliana, but sometimes slightly more open as in Figure $2 \mathrm{~d}$ and more closely resembling CAN 535850.

\section{Multivariate analysis}

The PCA (Figure 3a) shows that on Factor 1 (influenced by lemma, palea, and glume lengths, and extent of hair on paleas and lemmas) and Factor 2 (influenced by first glume width and anther length) species in $P$. section Pseudocolpodium separate from the $P$. arctica aggregate, and CAN 535850 groups in the centre of $P$. section Pseudocolpodium. When the P. arctica aggregate was removed (Figure 3b), CAN 535850 OTUs grouped between $P$. colpodioides and $P$. wrightii on Factor 1, which was most influenced by measurements of the inflorescence shape, and clusters more with $P$. wrightii on Factor 2, which is more influenced highly negatively by the first and second glume widths and callus hair length, and highly positively by the number of branches at the lowest node. The OTUs representing the single collection from CAN 535850 were dispersed almost as much as the separate collections from each of the other taxa.

\section{Discussion}

\section{Sectional alignment}

The specimen CAN 535850 aligns with Puccinellia sect. Pseudocolpodium based on the results from Table 1 and the ordinations in Figure 3. The specimen CAN 535850 and all of the species in $P$. sect. Pseudocolpodium have generally glabrous glume and lemma margins, whereas those in the $P$. arctica aggregate $(P$. poacea shown in Figure 2) are minutely scabrous. In addition, CAN 535850 and most of $P$. section Pseudocolpodium differ from the $P$. arctica aggregate by having generally longer glumes and longer lemmas with a wider hyaline margin.

\section{Puccinellia section Pseudocolpodium: species alignment}

The only taxon from this section recorded to date from Canada is $P$. vahliana. CAN 535850 differs from $P$. vahliana by having diverging inflorescence branches, a smaller inflorescence to height ratio, narrower glumes, and by lacking thick villous hair at the base of the palea. CAN 535850 also has longer primary inflorescence branches, larger anthers, and a larger ratio of anther to lemma, but there is some overlap in these three characters. The wide glumes of $P$. vahliana account for a "wrapping" effect of the glumes around the lower lemmas, especially visible when the spikelets are closed (see also P. colpodioides below). CAN 535850 is similar to $P$. vahliana in glume and lemma lengths (and ratios) and lemma hair characters.

The next closest taxon geographically, $P$. wrightii var. wrightii, is from Alaska and easternmost Russia. In comparison with $P$. wrightii, CAN 535850 differs by being shorter, having smaller ligules and shorter lemmas and paleas. They share, however, similar inflorescence branch divergence, length and width of glumes, hyaline lemma margins, longitudinal folds of the lemmas, long anthers, and hairiness of florets. The specimen CAN 535850 generally has four or five branches at the lowest node of the inflorescence. While the original description of $P$. wrightii indicated the lowermost branches in pairs, specimens from Alaska had up to six branches at the lowest node. The CAN 535850 specimen appears to be similar to $P$. wrightii, but less robust overall. This may be a consequence of our plant having grown in a more extreme environment.

The description of $P$. wrightii var. flava is based on only one collection from Port Clarence, Alaska. This variety was originally described as only differing from the typical variety by having yellow florets. In addition to this difference, we found that the lengths of first glume, second glume and lemmas are much larger than those of $P$. wrightii var. wrightii, with no overlap. The ratios of these values, however, are similar to the rest of $P$. sect. Pseudocolpodium. These very large length values account for the low number of similarities with CAN 535850. Moreover, CAN 535850 has straw-coloured to greenish-red florets with a bronze tinge, as opposed to yellow florets.

The remaining taxa in this subgenus are known only from Russia. CAN 535850 keys out intermediate to $P$. colpodioides and P. byrrangensis in Tzvelev's treatment (1976). Puccinellia colpodioides is a smaller plant than $P$. wrightii, and the lemma length of CAN 535850 overlaps more with the smaller lemma of $P$. colpodioides than with that of $P$. wrightii. Some of the inflorescence characters (primary branch length, maximum divergence of inflorescence branches) of CAN 535850 are similar to those of $P$. colpodioides, but the former differs by having a smaller ratio of inflorescence to plant height, a generally open inflorescence, with 4-5 branches at the lowest node, narrow glumes, 


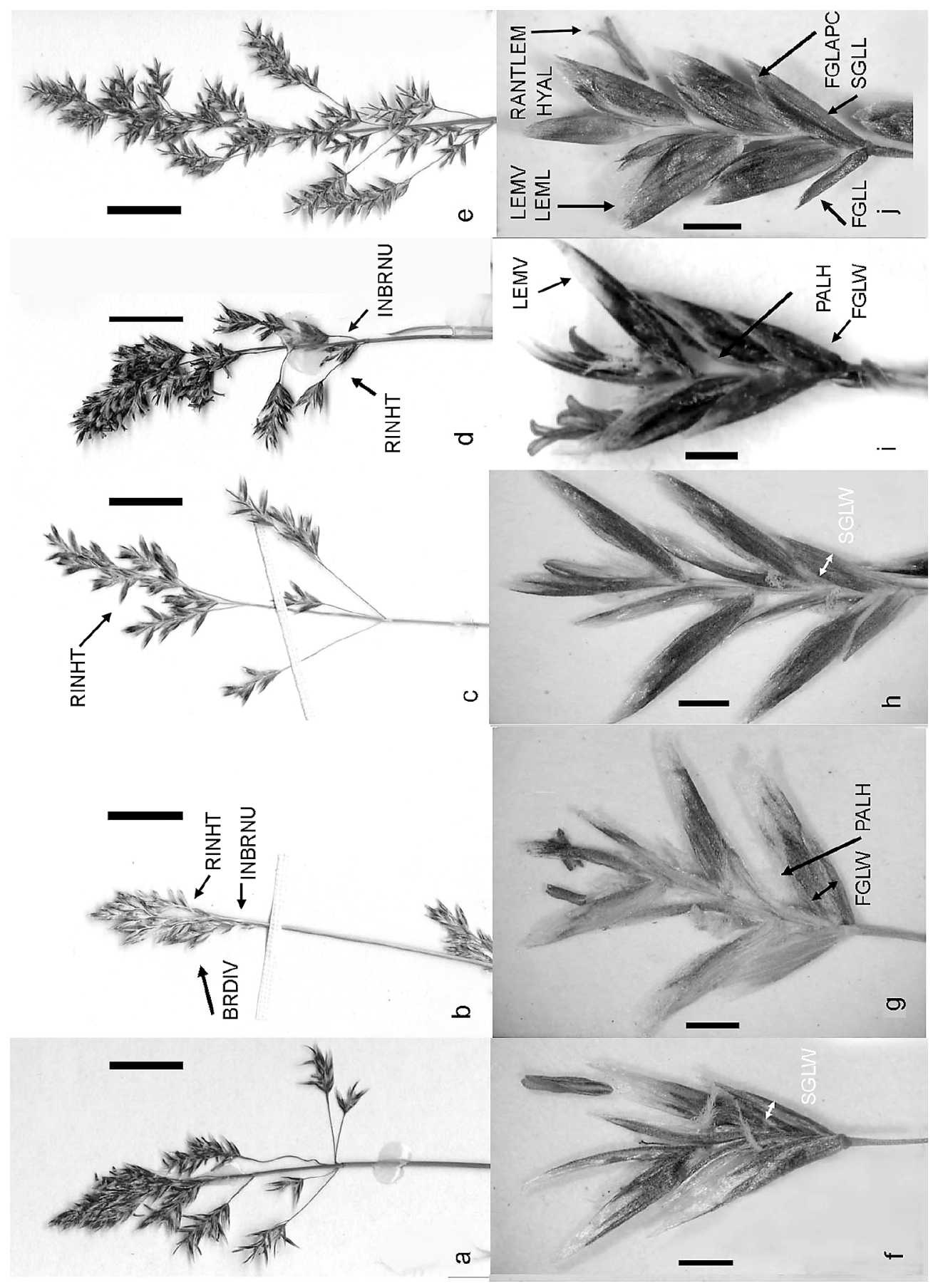

FIgURE 2. Photographs of five species in Puccinellia section Pseudocolpodium taken under a stereomicroscope. (a-e) Inflorescences, scale bar length $=1 \mathrm{~cm}$. (a) CAN 535850, (b) Puccinellia vahliana, (c) P. wrightii, (d) P. colpodioides, (e) $P$. poacea. (f-j) Spikelets, scale bar length $=1 \mathrm{~mm}$. (f) CAN 535850, (g) Puccinellia vahliana, (h) P. wrightii, (i) P. colpodioides, (j) P. poacea. Black and white arrows show features that differ from those of CAN 535850. Abbreviations for the character codes are given in Table 1. 

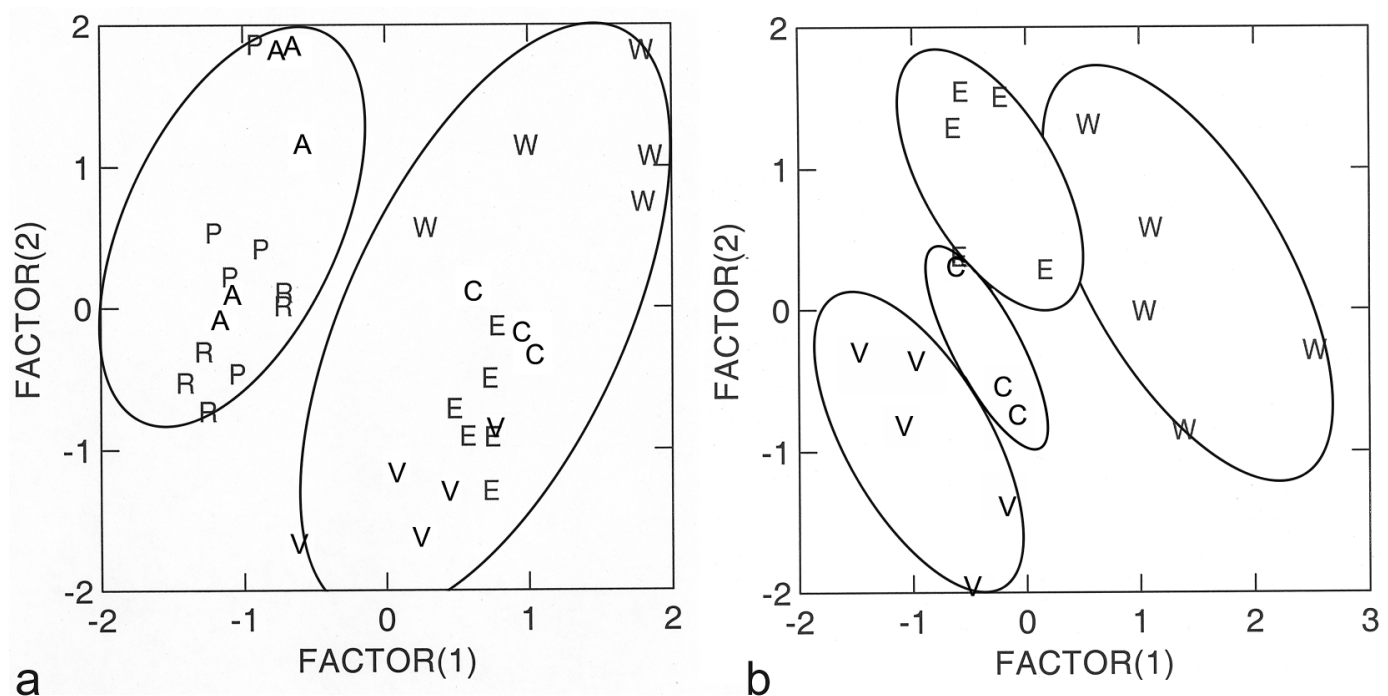

FIGURE 3. Principal components analysis. (a) Analysis on full dataset (b) Analysis on dataset without $P$. arctica aggregate. Section Pseudocolpodium: $\mathrm{E}=\mathrm{CAN} 535850, \mathrm{~V}=P$. vahliana, $\mathrm{C}=P$. colpodioides, $\mathrm{W}=P$. wrightii; Species of $P$. arctica aggregate, section unassigned: $\mathrm{A}=P$. arctica, $\mathrm{P} .=P$. poacea, $\mathrm{R}=P$. agrostidea .

and silky hairs on the palea keels rather than villous hairs on the lower palea keels, similar points of difference to $P$. vahliana. Thus, although the specimen does resemble $P$. colpodioides superficially, close examination of the spikelets suggests that CAN 535850 is not as closely aligned to $P$. colpodioides as to $P$. wrightii. Moreover, $P$. colpodioides has wide glumes similar to those of $P$. vahliana, which makes these two species closer in appearance to each other than to CAN 535850.

Both CAN 535850 and P. byrrangensis have very wide hyaline margins, but this is a rather variable character in CAN 535850. These species also share obvious folds on the lemma. On the other hand, the panicle was described as contracted for $P$. byrrangensis, unlike CAN 535850 which is most often open. The palea keels are glabrous or at most very slightly pilose in P. byrrangensis, unlike those of CAN 535850 which are slightly scabrous distally. Thus, differences in inflorescence characters indicate that CAN 535850 is unlikely to be $P$. byrrangensis, a species endemic to the Taimyr, west Siberia and considered by Tzvelev (1964) to be intermediate between $P$. vahliana and $P$. colpodioides.

The distribution gap between CAN 535850 and both $P$. beringensis and $P$. jenesseinsis make it unlikely that the former belongs to either of these species. Puccinellia beringensis is reported to have paleas that are glabrous and smooth or with solitary spinules, and anthers 1-1.4 mm long (Tzvelev 1976). In contrast, CAN 535850 has paleas that are slightly scabrous and anthers 1.6-1.8 mm long. Moreover, Probatova (1985) did not even classify $P$. beringensis in section Pseudocolpodium [although Tzvelev (1976) did], but instead placed it in section Puccinellia. Puccinellia jenesseinsis has paleas that are glabrous or with only a few hairs basally, and inflorescences that are lax and broadly diffuse (Tzvelev 1964, 1976). Tzvelev (1964) described the lemmas as definitely lacking longitudinal folds, whereas in 1976 he said the lemmas were often longitudinally folded when dry. CAN 535850 has slightly scabrous veins to the palea as well as a few basal hairs, inflorescences that are open at the base only, and strong longitudinal folds.

From the above comparisons, CAN 535850 aligns most closely with typical $P$. wrightii, although the florets were smaller overall, which may explain why it keyed out closer to the smaller taxon P. colpodioides. In summary, CAN 535850 had palea hair characters resembling $P$. wrightii, glume length similar to $P$. wrightii, lemma size characteristics of $P$. byrrangensis, $P$. colpodioides, and $P$. vahliana, and the hyaline margins and longitudinal folds of $P$. wrightii and $P$. byrrangensis. Although intermediate, it is unlikely a hybrid because it is allopatric from all taxa except $P$. vahliana.

Although CAN 535850 is different from all of the other species of Puccinellia section Pseudocolpodium we do not choose to base the description of a putative new taxon on a single specimen. The species in section Pseudocolpodium are very similar morphologically and in our PCA form a continuum as was found for other Puccinellia species complexes in Consaul and Gillespie (2001). CAN 535850 falls with P. colpodi- 
oides between $P$. vahliana and $P$. wrightii in morphological characteristics. It conservatively aligns closest to $P$. wrightii, to which it conforms to a small specimen, as much as to $P$. wrightii var. flava is larger. Puccinellia wrightii may be an aggregate species complex which includes the larger $P$. wrightii forms and the smaller forms such as $P$. colpodioides and CAN 535850. The latter two may provide an evolutionary link between the allopatric species $P$. wrightii and P. vahliana.

\section{Taxonomy}

Puccinellia wrightii var. flava (Scribn. \& Merr.) Consaul, comb. nov. Based on Colpodium wrightii subsp. flavum Scribn. \& Merr., Contributions of the United States National Herbarium 13: 75. 1910. The single collection upon which this name is based is more yellow in colour and has larger glumes and florets than in the typical variety. The collection locality lies within the distribution of $P$. wrightii var. wrightii and collection notes on specimens suggest the habitats are similar; we, therefore, give this taxon only varietal status.

Note: The combination Puccinellia wrightii (Scribn. \& Merr.) Tzvelev was published in two places in 1964: Fl. Arct. URSS (Arkticheskaya flora SSSR), Fasc. II, 193. 1964 (IK), and Novosti Sist. Vyssh. Rast. 1964: 19 (GCI). Notes in the respective publications indicate that the former was signed off for publication 18 July 1964 and the latter 14 September 1964. Therefore, the former is the proper citation for the publication of the name $P$. wrightii.

\section{Acknowledgments}

We thank Carolyn Parker and Vladim Federov for translation of Russian on herbarium labels, and we also thank the former for providing us with geographical coordinates for some of the more obscure Russian localities. The curators at ALA and US are thanked for loans of specimens. We thank W. J. Cody for collecting $P$. arctica from the Yukon. The Polar Continental Shelf Project is thanked for funding and logistic support for field work, and the Aurora Research Institute and Nunavut Research Institute are thanked for logistic support in the field. J. McNeill, Royal Botanical Gardens, Edinburgh, is thanked for comments and help with nomenclature. Two anonymous reviewers are thanked for constructive comments on the manuscript. This research was funded by the Canadian Museum of Nature. This is Polar Continental Shelf publication \#023-06.

\section{Documents Cited (marked * in text)}

Aiken, S. G., L. L. Consaul, and M. J. Dallwitz. 22 November 2000. Poaceae of the Canadian Arctic Archipelago: Descriptions, Illustrations, Identification, and Information Retrieval. Version: $22^{\text {nd }}$ November 2000. http: //www.mun.ca/biology/delta/arcticf/(1995 onwards).
Watson, L., and M. J. Dallwitz. 1999. Grass Genera of the World: Descriptions, Illustrations, Identification, and Information Retrieval; including Synonyms, Morphology, Anatomy, Physiology, Phytochemistry, Cytology, Classification, Pathogens, World and Local Distribution, and References. Version: $18^{\text {th }}$ August 1999. http://biodiversity.uno.edu/delta/ (1992 onwards).

\section{Literature Cited}

Cody, W. J. 1996. Flora of the Yukon Territory. National Research Council, Research Press, Ottawa, Ontario, Canada.

Consaul, L. L., and L. J. Gillespie. 2001. A re-evaluation of species limits in Canadian Arctic Island Puccinellia (Poaceae): resolving key characters. Canadian Journal of Botany 79: 927-956.

Davis, J. I. 1983. A systematic treatment of the Puccinellia nuttalliana complex. Ph.D. thesis, University of Washington, Seattle, Washington.

Davis, J. I. 1993. Puccinellia howellii (Poaceae) is genetically distinct. Madrono 40: 202-208.

Fernald, M. L., and C. A. Weatherby. 1916. The genus Puccinellia in eastern North America. Rhodora 18: 1-23.

Gould, F. W., and R. B. Shaw. 1983. Grass Systematics, second edition. Texas A\&M University Press, College Station, Texas.

Hultén, E. 1968. Flora of Alaska and neighboring territories. Stanford University Press, Stanford, California.

Holmgren, P. K., N. H. Holmgren, and L. C. Barnett. 1990. Index herbariorum, Part I: The Herbaria of the World. $8^{\text {th }}$ Edition. New York Botanical Garden, New York.

Malyshev, L. I., and G. A. Peshkova. Editors. 1990. Flora of Siberia [Flora Sibiriae]. Volume 2 Poaceae (Gramineae). Novosibirsk. [In Russian].

McRae, D., R. Stitt, and N. C. Wilson. 1994. A southern breeding range extension of the Lesser Snow Goose, Chen caerulescens caerulescens, James Bay, Ontario. Canadian Field-Naturalist 108: 223.

Polunin, N. 1940. Botany of the Canadian Eastern Arctic. Part. 1. Pteridophyta and Spermatophyta. National Museum of Canada Bulletin Number 92.

Polunin, N. 1959. Circumpolar Arctic Flora. Clarendon Press, Oxford, United Kingdom.

Probatova, N. S. 1985. Puccinellia. Pages 310-321 in Plantae vasculares orientis extremi Sovietici. Edited by S. S. Charkevicz, Tomus 1, Nauka, Leningrad. [In Russian].

Tzvelev, N. N. 1964. Puccinellia Parl. - alkali grass. In Flora of the Russian Arctic. Arkitcheskaya flora SSSR, Volume 2 (Gramineae). Edited by A. I. Tolmachev. USSR Academy of Sciences, Komarov Botanical Institute. [Translated from Russian by G.C.D. Griffiths. Edited by J.G. Packer. University of Alberta Press, Edmonton. 1995. pp. 237-263.]

Tzvelev, N. N. 1976. Zlaki SSSR. Nauka, Leningrad, Russia. [Grasses of the Soviet Union, Translated from Russian by Amerind Publishing Co., New Delhi, 1983].

Welsh, S. L. 1974.. Anderson's Flora of Alaska and adjacent parts of Canada. Brigham Young University Press, Provo, Utah.

Received 22 August 2002

Accepted 13 September 2005 


\section{Appendix 1}

Specimens examined in the morphological analyses (names of authors of current paper abbreviated by initials). Herbarium code in parentheses; abbreviations from Holmgren et al. 1990). Specimens used in PCA coded by ${ }^{p}$.

CAN 535850 - N.W.T.: Banks Island, Egg River, Area \#16, K. L. MacInnes s.n., 24 July 1971, (CAN) P. P. agrostidea - NUNAVUT, Banks Island: De Salis Bay. $71^{\circ} 26^{\prime} \mathrm{N}, 121^{\circ} 40^{\prime} \mathrm{W}$., 31 July 1949, A. E. Porsild 17614 (CAN) Holotype ${ }^{\mathrm{p}}$; Ellesmere Island: Lake Hazen. 81 ${ }^{\circ} 49^{\prime} \mathrm{N}, 71^{\circ} 20^{\prime}$ W., 8-10 Aug. 1961, $C$. R. Harington, $355(\mathrm{CAN})^{\mathrm{p}}$; Caledonian Bay. $79^{\circ} 57.23^{\prime} \mathrm{N}$, 81 11.96"W., 9 Aug? 1972, Waterton, I. W207 (CAN) ; Victoria Island: Cambridge Bay. $69^{\circ} 07^{\prime} \mathrm{N}, 105^{\circ} 03^{\prime} \mathrm{W} ., 12$ August 1959, Porsild, A. E. 21599 (CAN) ${ }^{\mathrm{p}} ; 6^{\circ} 07^{\prime} \mathrm{N}, 105^{\circ} 03^{\prime} \mathrm{W} ., 12$ August 1959, Porsild, A. E. $21597(\mathrm{CAN})^{\mathrm{p}}$. P. arctica NUNAVUT: Victoria Island: Cambridge Bay, $69^{\circ} 08^{\prime} \mathrm{N}$, $105^{\circ} 10^{\prime} \mathrm{W}, L J G \&$ \& LC 6321 (CAN); LJG \& LLC 6322; $L J G \&$ \&LC 6342 (CAN); NWT: Anderson River Delta, $69^{\circ} 40.66^{\prime} \mathrm{N}, 128^{\circ} 54.92^{\prime} \mathrm{W}, L J G \&$ L LC 6362 (CAN); Atkinson Point, appr. $70^{\circ} \mathrm{N}, 131^{\circ} 20^{\prime} \mathrm{W}$, A. E. \& R. T. Porsild 2549 (CAN); Cape Dalhousie, $70^{\circ} 11.28^{\prime} \mathrm{N}, 129^{\circ} 40.96^{\prime} \mathrm{W}$, A. E. \& R. T. Porsild $2710(\mathrm{CAN})^{\mathrm{p}}$; Tuktoyaktuk, $69^{\circ} 27^{\prime} \mathrm{N}$, $133^{\circ} 02^{\prime} \mathrm{W}$, A. E. Porsild 7404p; J. M. Gillett 18669 (CAN)p; J. M. Gillett $18787(\mathrm{CAN})^{\mathrm{p}}$; Yukon: Herschel Island, W. J. Cody $36154(\mathrm{CAN})^{\mathrm{p}}$. P. colpodioides - RUSSIA: prov. Magadan, Wrangel Is., 27 July 1970, V. Petrovsky 6303 (ALA) ${ }^{\mathrm{p}}$; R.P Nebrobikuit, 28 July 1972 (ALA)p; Somnitelnay Bay, vic. Zvzdnyy, approx. $70^{\circ} 50^{\prime} \mathrm{N}, 179^{\circ} 30^{\prime} \mathrm{W}$, V.V. Petrovsky. 7 August 1971 (voucher 2n=14) (ALA) $)^{\mathrm{P}}$ P. poacea - NUNAVUT: Axel Heiberg Island: Diana Lake, appr. $79^{\circ} 30^{\prime} \mathrm{N}$, $88^{\circ} 30^{\prime} \mathrm{W}$, A. E. Porsild $18640(\mathrm{CAN})^{\mathrm{p}}$; A. E. Porsild 18641 $(\mathrm{CAN})^{\mathrm{p}}$; Mokka Fiord, 79 $29^{\prime} \mathrm{N}, 87^{\circ} 22^{\prime} \mathrm{W}, L J G \&$ C. Vogel 6087 (CAN); Ellesmere Island: Hazen Camp, 81 ${ }^{\circ} 49^{\prime} \mathrm{N}$, $71^{\circ} 20^{\prime} \mathrm{W}$, LJG \& C. Vogel 6215 (CAN); LJG \& C. Vogel 6216 (CAN); LJG \& C. Vogel 6217 (CAN); Hot Weather Creek, $79^{\circ} 58^{\prime} \mathrm{N}, 8^{\circ} 26^{\prime} \mathrm{W}, L J G \&$ C. Vogel $6132(\mathrm{CAN}) ; L J G \& C$. Vogel $6144(\mathrm{CAN}) ;$ LJG \& C. Vogel $6150(\mathrm{CAN}) ;$ LJG \& C.

\section{Appendix 2}

Morphology and Habitat Description of CAN 535850

Plants 8-18 cm tall; uppermost ligule 0.9-1.0 mm long; inflorescence $2.0-4.0 \mathrm{~cm}$ long, inflorescence length to plant height ratio 0.17-0.25; inflorescence lowest branches ascending to horizontal, (2-) 4-5 branches at the lowest node; first glume 2.1-2.2 mm long, 0.6-0.8 mm wide; second glume 2.9-3.2 mm long, 0.7-1.0 mm wide; lemma 3.5-4.0 mm long, with moderate to very wide hyaline margin, longitudinal ridges distinct, base pilose to moderately villous on and between the veins; palea keels distally moderately scabrous, basally glabrous to slightly pilose; anthers $1.6-1.8 \mathrm{~mm}$ long. Differs from $P$. colpodioides and $P$. vahliana by its open panicle, smaller ratio of inflorescence to height, relatively narrower glumes, and non-villous palea keel bases; from $P$. wrightii by its larger ratio of inflorescence to height and shorter lemma with a wider hyaline margin; from $P$. wrightii var. flava by its non-yellow colour of florets and smaller glumes, lemma and palea, and longitudinal ridges on lemma.
Vogel 6151 (CAN); Slidre Fiord, appr. $80^{\circ} 00^{\prime} \mathrm{N}, 85^{\circ} 57^{\prime} \mathrm{W}, J$. S. Tener 33 (CAN); J.S. Tener 35, (CAN) Holotypep; J. S. Tener $34(\mathrm{CAN})^{\mathrm{p}}$; Tanquary Fiord, $81^{\circ} 24^{\prime} \mathrm{N}, 76^{\circ} 52^{\prime} \mathrm{W}, J . S$. J. Haight $6(\mathrm{CAN})^{\mathrm{p}}$. P. vahliana - NUNAVUT: Baffin Island: Nanisivik Airport, $73^{\circ} 02^{\prime} \mathrm{N}, 84^{\circ} 33^{\prime} \mathrm{W}, L J G, L L C$ \& R. J. Soreng $6691(\mathrm{CAN})$; Savage Harbour. $61^{\circ} 50^{\prime} \mathrm{N}$, $65^{\circ} 45^{\prime} \mathrm{W}$, V. C. Wynne-Edwards $7301(\mathrm{CAN})^{\mathrm{p}}$; Cornwallis Island: Resolute Bay, $74^{\circ} 41^{\prime} \mathrm{N}, 94^{\circ} 50^{\prime} \mathrm{W}, L J G$ \& C. Vogel 6249 (CAN); A. E. Porsild $21649(\mathrm{CAN})^{\mathrm{p}}$; Devon Island: Dundas Harbour, $74^{\circ} 31.3^{\prime} \mathrm{N}, 82^{\circ} 33.5^{\prime} \mathrm{W}, L J G, L L C \& R . J$. Soreng 6697 (CAN); Ellesmere Island: Caledonian Bay, $79^{\circ} 57.23^{\prime} \mathrm{N}, 81^{\circ} 11.96^{\prime} \mathrm{W}$, LLC \& LJG 2219 (CAN); Craig Harbour, $76^{\circ} 12^{\prime} \mathrm{N}, 81^{\circ} 01^{\prime} \mathrm{W}$, J. D. Soper $111374(\mathrm{CAN})^{\mathrm{p}}$; Hazen Camp, 81 ${ }^{\circ} 49^{\prime} \mathrm{N}, 71^{\circ} 20^{\prime} \mathrm{W}, L J G 6012$ (CAN); NWT, Banks Island: near Cape Lambton, $71^{\circ} 05^{\prime} \mathrm{N}, 123^{\circ} 09^{\prime} \mathrm{W}, A$. E. Porsild 17539 (CAN) $^{\mathrm{p}}$; Melville Island: Ibbett Bay Camp, $75^{\circ} 54^{\prime} \mathrm{N}, 114^{\circ} 30^{\prime} \mathrm{W}$, S. G. Aiken \& S. A. Edlund 3936 $(\mathrm{CAN})^{\mathrm{p}}$. $\boldsymbol{P}$. wrightii - RUSSIA: Chukotka Peninsula, in the vicinity of the Chaplin Cape, 20 July 1958, R. Satpuisau s.n. (ALA) $^{\mathrm{p}}$; Chukotka Peninsula, SE tip of Cape Chaplino, approx. $64^{\circ} 25^{\prime} \mathrm{N}, 172^{\circ} 15^{\prime} \mathrm{W}, 20$ July 1958, V. Gavreluk (ALA) $^{\mathrm{p}}$; Chukotka Peninsula, eastern region, S coast of Lavrentiya Bay, vicinity of Lavrentiya, approx. $65^{\circ} 45^{\prime} \mathrm{N}$, $171^{\circ} \mathrm{W}, 29$ August 1971, N. A. Sekretarova, A. K. Sitinn, B. A. Yurtsev (ALA) ${ }^{\mathrm{p}}$; Chukotka Peninsula, eastern tip, vicinity of Uelen, approx. $66^{\circ} 10^{\prime} \mathrm{N}, 169^{\circ} 50^{\prime} \mathrm{W}, 25 \mathrm{Aug} .1971, N$. A. Sekretarova, A. K. Sitinn, \& B. A. Yurtsev (ALA) ; SW portion of Chukotka peninsula, right bank of Senevem R., 15 km above mouth. 24 July 1983, A. E. Katenen \& N. A. Sekretarova (ALA); W. Chukotka, Anyuyskiy Mountains, upper Vernitakatvem River, 12 July 1974, T. Koraseva and V. Petrovsky (ALA), voucher 2n=14; Siberia, Arakamtchetchene or Kayne Island, C. Wright (US ex NA 592344) (Holotype). USA: Alaska, Teller Quad., Cape Prince of Wales, $65^{\circ} 37^{\prime} \mathrm{N}, 168^{\circ} 05^{\prime} \mathrm{W}, 18$ August 1982, T. Kelso 82230 (ALA); P. wrightii var. flava: Alaska, Port Clarence, $65^{\circ} 16^{\prime} \mathrm{N}, 166^{\circ} 51^{\prime} \mathrm{W}$. F. A. Walpole 1891a (US 379007) (Holotype).

Specimen CAN 535850 was found above the Egg River floodplain in a transition zone between a slightly steeper slope with soil stripes and more pronounced Dryas/Salix hummocks below, and a more open summit zone with Dryas, Salix, Saxifraga tricuspidata Rothb. and Cetraria above. The collection site had a gradual slope, with $30 \%$ ground cover of rounded soil mounds or micropolygons, and predominantly Dryas/Salix cover. The plant was found on the bare to partly bare tops of these low Dryas mounds, with salt crust, sand, pebbles and desiccation cracks containing lichens and mosses. Scattered small depressions in the area contained predominantly sedges and grass, as well as Cassiope tetragona (L.) D.Don. Other associated herbs in the general area were: Hulteniella integrifolia (Richardson) Tzvelev, Parrya arctica R.Br., Saxifraga oppositifolia L., Astragalus alpinus L., Pedicularis capitata Adams, and Pedicularis langsdorfii subsp. arctica (R. Br.) Pennell. 